DOI: 10.17065/huniibf.309271

IMF:

\section{DÜN VE BUGÜN}

\section{Korkut BORATAV}

Ankara Üniversitesi

SBF Emekli Öğretim Üyesi
Hacettepe Üniversitesi iktisadi ve Idari Bilimler

Fakültesi Dergisi,

Cilt 34, Sayı 1, 2016

s. $27-42$

7 Aralı 2014'te Hacettepe Üniversitesi'nde 70.

Yllında Bretton Woods Anlaşmast

Sempozyumu'nda ve 5 Şubat 2015 'te Dokuz

Eylül Üniversitesi'nde ayn konuda yapılan iki

konuşmanin birleştirilmesinden oluşmuştur.

Davetli konuşmacı tebliğidir.

Hakem sürecine dahil edilmemiştir. 
Değerli izleyiciler,

Bretton Woods kurumlarının oluşumu, tarihçesi üzerinde gerekli ön-bilgilerin sabah oturumunda verildiğini, analizlerin yapıldığını; bunların bu oturumdaki diğer bildirilerde de sürdürüleceğini tahmin ediyorum.

Ben, bu kurumlardan IMF üzerinde duracağım. Özellikle IMF'nin işlevlerinde, perspektiflerinde, üye ülkelerle ilişkilerinde zaman içinde ne gibi değişiklikler olduğuna dikkat çekmek istiyorum.

$\mathrm{Bu}$, elbette, çok iddialı bir gündem oluşturuyor. Kapsamlı bir tarihçeye kalkışmam mümkün değil. Bunun yerine kuşbakışı bir gezinti yapacağım. Önce, kuruluş tarihiyle günümüz arasında IMF’nin işlevlerinde meydana gelen değişimlere ana çizgileriyle değineceğim.

Bu gezintinin büyük bölümü, 1970'li yılların sonunu izleyen otuz yıllık bir zaman diliminde Üçüncü Dünya ülkelerinde uygulanan IMF programlarının bazı ortak özellikleriyle ilgili olacak. Bu çok kapsamlı konuyu da burada sistematik olarak incelemem mümkün değil. Birkaç kritik soru üzerinde odaklaşan değinmelerin konuya en azından ışık tutacağını umuyorum.

ABD'de patlak veren ve özellikle emperyalist metropolleri ilgilendiren 20072008 krizi sonrasında IMF'ye yeni görevler verildi. Son olarak da bu yeniliğin, IMF'ye egemen olan iktisat düşüncesinde ve uygulamalarda herhangi bir değişime yol açıp açmadığını gözden geçireceğim.

\section{ANA SÖZLESMMENIN “UYUYAN” MADDELERİ}

Önceki bildirilerde tartışıldığını biliyorum; ama yine de kısaca tekrarlayayım: Bretton Woods Konferansı, dünya ekonomisinin işleyiş kurallarını ABD hegemonyasının sürekli olacağı varsayımına göre oluşturdu.

İlk olarak doların dünya parası olması kararlaştırıldı. Dolar altına, diğer ulusal paralar da sabit kurlarla dolara bağlanmaktaydı. Böylece belirlenen döviz kurlarında istikrart ve ödemeler dengesi sorunların izleyecek kurum IMF oldu.

$\mathrm{Bu}$ iki hedef birbiriyle ilgilidir. Sermaye hareketleri ulus devletler tarafindan denetlenebilir; bu nedenle dış denge sorunları, dış ticaret açık ve fazlaları biçiminde ortaya çıkar. Sabit kurlar rejimi, dış ticaret dengesini etkilemeyi hedefleyen rekabetçi devalüasyonları önler. Kurlardaki değişiklikler, ancak IMF'nin onayı ile yapılabilir. Bu 
değişiklikler de dış ticaret dengelerinde sürekli istikrarsızlıklar (yani açıklar ve fazlalar) oluştuğunda gündeme gelir.

Böyle bir durumda diş fazla veren ülke mi; dış açık veren ekonomi mi uyum yükümlülüğünü üstlenmelidir? $\mathrm{Bu}$ soru üzerinde Bretton Woods Konferansı'nda Keynes (yani Britanya) ve White (yani Amerikan) tezleri tartıştı. Sonunda Amerikan tezi egemen oldu: Dış ticaret dengelerinde kalıcı bir istikrarsızlık ortaya çıktığında uyum yükümlülüğü, yani devalüasyon açık veren ekonominin yükümlülüğü olarak belirlendi. Devalüasyonun başarılı olması için de iç talebi daraltıcı politikalar uygulanmalıdır. Devalüasyon oranını ve talep daraltıcı önlemleri açık veren ekonomiye taşımak, uygulatmak ve geçiş döneminin finansmanı (kredisi) IMF'nin görevi olur.

ABD’nin reddettiği Keynes taslağı kabul edilseydi, uyum yükümlülüğü 'ticaret fazlası veren ekonomi” tarafından üstlenilecekti. Bu yükümlülük, iç talebi genişleten makro-ekonomik önlemlerden ve revalüasyondan (yani paranın dış değerini açık veren ülkelere karşı yükseltmekten) oluşacaktı. İç talep genişlemesi, fiyat düzeyini yukarı çektiği ölçüde reel revalüasyon gerçekleşmiş olur; nominal kur değişiklikleri sınırlı tutulabilir.

$\mathrm{Bu}$ iki sistem arasındaki temel fark, kabul edilen sistemin deflasyonist (daraltıcı) bir sapma içermesidir. Dünya ekonomisinde açıklar ile fazlalar birbirini denkleştirdiğine göre, sistemin açık veren ülkelerinin daraltıcı politikalara yönlendirilmesi, dünya ekonomisini de aşağı çeker. Sistemin fazla veren blokunda genişletici politikalar zorunlu kılınsaydı, dış dengesizliklerin dünya ekonomisini yukarı çeken yöntemlerle düzeltilmesi mümkün olacaktı.

Bu iki alternatife 1şık tutacak bir örnek vereyim. Bu örnek, aslında, konuşmamın sonlarında ele alacağım dönemle ilgilidir; ama buraya da uygundur. 2010'da patlak veren $\mathrm{AB}$ krizinde, Avro Bölgesi'nin dış açık ve fazla veren iki bloku karşı karşıya geldi. Krize karşı hangi seçenek uygulanmalıydı? Tepkilerde ortaya çıktı. Almanya, Avro Bölgesi'nin zayıf halkalarına (İspanya, Portekiz, Yunanistan ve İtalya’ya karşı) dış fazla veriyor. Bretton Woods da Keynes'in tezlerini yetmiş yıl sonrasının Keynes'gil iktisatçıları savundular ve Almanya'ya, "genişleyici maliye ve para politikaları uygula ki, ithalatın artsın, enflasyon başlasın, Güney Avrupalılar Almanya'ya ihracat yapabilecek, dış açıklarını frenleyecek rekabet gücünü kazansınlar" çağrısını yaptılar. Almanya ise, “avro'nun dĕgeri sabit olduğuna göre, Yunanistan, İspanya ve diğerleri, iç taleplerini kısarak, ücretleri aşağı çekerek (yani içsel devalüasyonla) rekabet güçlerini artırsınlar" reçetesinde 1 srarcı oldu. IMF modeli egemen oldu; reçete, açık veren ülkelerde (nominal devalüasyon hariç) eksiksiz uygulandı. Sabit avro'nun katkısı nedeniyle reçeteyi uygulayanlar dramatik (Yunanistan'da \%25'e ulaşan) oranlarda küçüldü. 
Bretton Woods modeli, 1944'te kalıcı olacağı varsayılan ABD'nin ekonomik üstünlüğüne bağlıydı. Ancak, bu üstünlük zaman içinde kayboldu. Almanya ve Japonya dünya sisteminin ihracat merkezleri olarak öne çıtılar. Amerikan emperyalizmi, özellikle Vietnam savaşı sonunda ABD'yi dış açı veren bir konuma sürükledi. 1971'de Nixon dolar-altın bağlantısına son verdi. Doların dış değeri düşürüldü; yani devalüasyon yapıldı. İki yıl sonunda esnek döviz kurları rejimine geçildi.

Öte yandan, IMF Ana Sözleşmesi'ndeki "deflasyonist sapma”, otuz yıl boyunca Üçüncü Dünya ülkelerini fazla etkilemedi. Bu dönem "Kapitalizmin Altın Çağı" olarak adlandırılır. Keynes'in tezleri IMF'nin ana sözleşmesine girmemiş̧ir; ama dünya ekonomisinin metropolü ile çevresi arasındaki ilişkiler, "uluslararası Keynes'gil" ilkelere göre biçimlenmiştir. Üçüncü Dünya korumacı dış ticaret politikaları uygulayabilir; iç pazara dönük sanayileşme bir yandan ithal ikamesi ile sürdürülür; yerli üretim korunduğu için dış ticaret açıkları frenlenir. Ancak, sanayileşmenin gerektirdiği yatırım malı ve girdi ithalatı nedeniyle dış ticaret açığı verilir; ancak, bunlar genellikle 1lımlı düzeylerde kalır ve metropolün ucuz dış kaynak akımlarıyla kapatılır. Açıklar çok artarsa, IMF yukarıda değindiğim devalüasyonu ve daraltıcı makro politikaları gündeme getirir; ancak, bu istisnai bir uygulamadır. Örneğin otuz yıllık bir zaman aralığında Türkiye IMF ile sadece bir kere kredi anlaşması yapmıştır. Buna karşlık, örneğin Britanya'da Callaghan hükümeti 1976 'da IMF ile 2,3 milyar sterlin'lik bir kredi anlaşması yapmak zorunda kalmıştır.

Kısacas1, 1945'i izleyen otuz y1llık "Altın Çağ" boyunca, Bretton Woods sisteminin mantığında yer alan "daraltııı istikrar politikaları" modeli, metropol/çevre ilişkileri açısından IMF ana sözleşmesinin "uyuyan maddeleri" olarak kalmıştır. Emperyalizmin bağımlı kutbunu denetleyici, biçimlendirici bir işlev görmemiştir.

\section{“ÖLÜ MADDELER” UYANIYOR; IMF’NIN YENI İŞLEVI}

1974'teki OPEC'in petrol fiyatlarını sıçratan zammı, Batı ekonomilerini stagflasyona, küçülmeye sürükledi. Buna karşılık OPEC kökenli petro doların dolaşımı (resiklajı) para bolluğuna ve ucuz dış kredilere yol açtı. Petrol ihracatçısı olmayan çevre ekonomileri, ucuza borçlanmayı yüksek bir genişleme temposunu sürdürmek için kullandılar. Bu dönem, ayrıca, Üçüncü Dünya ülkelerinde bir radikalleşme de söz konusudur. 77'ler grubu altında toplanan Güney ülkeleri, "yeni bir uluslararası ekonomik düzen" kampanyası başlattılar; Batılılarla pazarlıklara dahi oturdular.

Üçüncü Dünya ekonomilerinde ihtiraslı büyüme, sanayileşme, ekonomik bağımsızlık, düzen değişikliği taleplerine karşı, emperyalizmin merkezinde bir tepki gereksinimi, bir disiplin arayışı başladı. Kritik bir karşı hamle, FED Başkanı Paul Volcker'in ABD politika faizlerini iki yıl içinde \%10'dan \%19'a çıkarması oldu. 
Yükselen faizler, Üçüncü Dünya'nın astronomik boyutlara ulaşmış dış kredilerine uygulandı. Sonuç, Latin Amerika'nın 1980'li yılların tümünü kapsayan borç krizidir. Türkiye de 1978-1980 yıllarında aynı kriz dalgasına sürüklendi.

Böylece, 1980'le birlikte, IMF'nin çevre ekonomilerine, Dünya Bankası ile birlikte neo-liberalizmi taşıdığı döneme geliyoruz. IMF’nin Ana Sözleşmesi'nde yer alan deflasyonist sapma, bir anlamda "hortladı"; istikrar politikaları başlı̆̆ altında, şevkle Üçüncü Dünya'ya uygulandı. İlginçtir ki, artık, sadece daraltıcı maliye ve para politikaları, yani istikrar programları değil, "piyasa dostu yapısal uyum politikaları" da gündeme gelmektedir. Bu iki Bretton Woods kurumu, birlikte, neo-liberalizmi Üçüncü Dünya'ya taşıdılar.

İlginçtir ki, Üçüncü Dünya neo-liberalizmi, Thatcher ve Reagan'ın Britanya ve ABD'de aynı modelin uygulanmasından öncedir. Friedman'ın Chicago Üniversitesi'ndeki yetiştirmeleri, 1973 Pinochet darbesi sonrasında Şili'ye neo-liberal politikaları taşıdılar. IMF henüz devreye girmemişti. Böylece, serbest piyasa ekonomisini 1980 öncesinin askeri darbe rejimleri içinde Latin Amerika'ya tanıtanlar, "Chicago çocukları" diye bilinen iktisatçılar oldu. Aynı yıllarda, IMF, henüz Batı dünyasında rağbet görmeyen neo-liberal uygulamaların çerçevesini, gerekçelerini, söylemlerini koruyan, istisnai durumlarda uygulamalara taşıyan bir "kuluçka" görevini üstlenmekteydi. Latin Amerika'nın 1980 krizleri sonrasında IMF'nin kuluçkası yavruladı; Türkiye dahil, emperyalist sistemin çevresinde yer alan çok sayıda ülkenin geleceğini biçimlendiren bir doktrin olarak ortaya çıktı.

\section{OTUZ YILLIK AĞIR BİR BİLANÇODAN KÜÇÜK KESITTLER}

Şimdi neo-liberalizmin çevre ekonomilerine taşındığı kabaca otuz yıllık bir döneme, 1978/80 ile 2007 arasındaki zaman kesitine bakacağım. Önce neo-liberalizmin gerçek adını koyalım: Sermayenin dünya çağında sınırsız tahakkümünü oluşturma tasarımına neo-liberalizm deniyor.

Sözünü ettiğim otuz yıl boyunca, bu tasarım, Latin Amerika, Asya, Güney ve Kuzey Afrika toplumlarını hallaç pamuğu gibi attı. Bazı yerlerde (Latin Amerika'da, Türkiye'de) askeri cuntalar tarafından hayata geçirildi. Bazı yerlerde "IMF ayaklanmaları" diye adlandırılan kalkışmaları tetikledi; 2002 sonunda Türkiye'de olduğu gibi iktidarların devrilmesine yol açtı. Farklı tarih mirasları içinde biçimlenmiş olan toplumları aynı kalıba sokmaya çalıştı. Sınıf mücadelelerinin devleti etkileyerek oluşan toplumsal yapıları, "serbest piyasa ekonomisi" denilen sahte bir söyleme göre biçimlendirdi. 
Bu otuz yıllık öyküyü özetlemem dahi mümkün değil. Bu büyük operasyonun çok sayıdaki arızalarının, tuhaf özelliklerinin bazılarına, birkaç soru sorarak dikkat çekmeye çalışacağım.

\section{IMF SIYYASETE MÜDAHALE EDER Mİ?}

IMF uluslararası bir kuruluştur. Her ne kadar üyelere eşit oy hakkı verilmemiş; oyların ağırlığı, anonim şirket gibi hisseler oranında olsa dahi, üye ülkelere siyasî müdahale yapması söz konusu olamaz.

Daha doğrusu "müdahale hakkı olmamalıdır" diyebiliriz. Zira, bu kural IMF tarafından sürekli olarak çiğnenmiştir.

İktisat politikası seçeneklerinde IMF programları siyasi iktidarların hükümranlık alanlarını elbette kısıtlar. Ancak, imzalama yetkisi hükümetlerde olduğu için, siyasi sonuçları, “dolaylı” olarak görülebilir. Örneğin 1978-79'da IMF’nin Ecevit hükümeti üzerinde çok katı bir programı kabul ettirme baskısı söz konusu idi. Bu baskı Türkiye'nin büyük sermayesi ile koordinasyon içinde yürütülmekteydi. Baskılar başarılı oldu; Ecevit hükümetinin istifası ile başlayıp, 12 Eylül darbesi ile noktalanan bir süreç oluştu. Ancak, bu tür sonuçlar, yansımalar, IMF tarafından "biz ekonomik programı hazırladık; darbe planı bize ait değildir" diye geçiştirilebilir.

Ne var ki, siyasete doğrudan müdahale örnekleri de vardır. 2008 sonrasındaki Avro Bölgesi krizinde ortaya çıkan bazı olgulara ileride değineceğim. Önceki dönemle ilgili birkaç örnek vermekle yetineyim.

Aralık 1997'de Doğu Asya krizi patlak vermiştir. Güney Kore ile IMF arasında çok ağır koşullar içeren stand-by anlaşması hazırdır. IMF imzayı geciktirir. Başkanlık seçimlerinde muhalefetin Başkanlık adayı Kim Dae-Jung’tan anlaşmaya uyma taahhüdü ister. Kredi anlaşması bu taahhüt verildikten sonra yürürlüğe girer.

Ocak-Mayıs 1998'de Endonezya, IMF'nin fiilen siyasi baskısı altında çalkantılara sürüklendi. IMF'nin Asya sorumlusu birkaç kere Başkan Suharto'ya anlaşma imzalattırd1; olmadı, yenisini, tekrar yenisini imzalattırdı. Bunlardan birinin fotoğrafı bugün gibi aklımdadır. Suharto’ya imzalayacağı belge verilmiştir. Hemen başucunda IMF yetkilisi belgeye bakmaktadır ve bir sömürge valisi üslubu ile imzanın atılışını kontrol etmektedir. Sonunda Suharto Başkanlıktan istifa etmek zorunda kalacaktır.

Bir de Türkiye örneği var: Mayıs 2005'te AKP, IMF'den üç yıllık ve 10 milyar dolarlık yeni bir kredi anlaşması talep eder. Anlaşma imzalanır, ama bu krediyi IMF, kendi normlarını çiğneyerek, ekonomik değil, siyasi öncelikler izleyerek vermiştir. 
Anlaşmanın kabulünü öneren IMF belgesi açıklamaktadır ki, AKP hükümetinin kredi talebi, bu tür başvurularda ön-koşul olarak aranan "ödemeler dengesi baskıları olmadığ için" gerekli ölçütleri içermemektedir. Türkiye'nin kredi talebi, "olağandışı koşullar" dikkate alınarak kabul edilmiştir. Hangi "olağandışı koşullar?" IMF’nin gerekçesi ilginçtir: "Ü̧̧ ylllık bir program Kasım 2007'de yapılacak olan genel seçimler için bir çıpa sağlayacaktır.” AKP'ye açık bir siyasi destek belgesi söz konusudur.

\section{IMF KIMİ GÖZETIR? ÜYELERINI Mİ? FINANS KAPİTALİ Mİ?}

IMF'nin üyeleri şirketler, bankalar değil; devletlerdir. Devletler-arası ekonomik anlaşmazlıklar (örneğin borç/alacak sorunları), IMF'nin yetki alanı içine giriyorsa, ana sözleşmenin kuralları ve genel iktisat-hukuk ilkeleri uygulanır. Buna karşılık, kapitalist dünya sisteminin doğası gereği, devletlerle şirketler, bankalar arasında ihtilaflar çıktığında bu kurumun kendi üyelerini, yani devletleri gözetmesi gerekir.

$\mathrm{Bu}$ genel ilke sürekli olarak çiğnendi. Çevre ülkelerinde patlak veren ekonomik krizlerde, finans kapitalin çıkarları, defalarca ve sistematik olarak bunalımdaki ülkenin (devletin) çıkarlarına karşı gözetildi. Tipik bir uygulama, krize sürüklenen ülkenin, uluslararası sermaye çevrelerine karşı özel borçlarının devlet tarafından üstlenilmesi ve IMF'nin devlete açtı̆̆ kredilerle alacaklıların "kurtarılması"dır. İleride değinmem gereken bir örneği burada verebilirim. 2010'da AB Komisyonu ve Avrupa Merkez Bankası ile birlikte Yunanistan devletine açılan IMF kredisi, Fransız ve Alman bankalarının alacaklarının bir bölümünün IMF alacağına dönüştürülmesi anlamındadır. Bankalar batık kredilerinin riskini üstlenmemişler, IMF tarafından kurtarılmışlardır.

Türkiye'den bir örnek: Tarih: Kasım 2000. Finansal krizin ilk belirtileri ortaya çıkmıştır. IMF'nin Avrupa koordinatörü Türkiye'ye gelir ve Başbakan Ecevit'i Türkiye bankalarının dış borçlarının da (aynen yerli mevduat gibi) Hazine garantisi altına alınması için ikna eder. Başbakan bu kararın yasal olmadığını fark etmez. Ecevit, bu kararı, IMF yetkilisi, Merkez Bankası Başkanı ve Hazine Müsteşarı ile ortak basın toplantısında kamuoyuna duyurur. Bir hafta sonra IMF’nin Genel Direktörü Köhler, Türkiye hükümetine, "Türkiye bankalarındaki mevduat sahiplerini ve diğer alacaklıları (yani yabancı bankaları) koruma kararı" nedeniyle teşekkür edecektir. Birkaç ay sonra, peş peşe batacak olan bankaların dış borçları, bu yasa-dışı yükümlülük nedeniyle T.C. hazinesi tarafından ödenecek; bu ödemelerin yol açtı̆̆ döviz gereksinimi IMF kredileriyle karşılanacaktı. Yasa-dışı garantiye ise, daha sonra güçlükle yasal bir kılıf biçilecektir.

Bu uygulama, ayrıca, IMF’nin yücelttiği "serbest piyasa doktrini”nin açık bir ihlâlidir. Özel kredi sözleşmeleri, risk olasıllğı içerir; borçlu ödeyemezse, alacaklı riskin sonuçlarına katlanır; iflâs masasına girer. Kredinin devlet tarafından üstlenilmesi ise 
ahlâkî bozulma (İngilizcesi "moral hazard”) örneği olarak neo-klasik ders kitaplarında okutulur.

\section{ÜLKELER VE LABORATUVARLAR: IMF ULEMASINDA BILLIMSEL ETIK SORUNLARI}

Bretton Woods kurumlarının uzmanları, yöneticileri önerdikleri, uygulattıkları programların ekonomik-toplumsal yıkım boyutlarına ulaşan kimi sonuçlarının sorumluluğu ile nasıl hesaplaşıyorlar?

$\mathrm{Bu}$ soruyu tartışırken karşılaştı̆ı̆ kimi örnekler, beni, ister istemez, "bu insanlarda hiç vicdan yok mu?” tepkisine sürüklüyor.

Bir örneği, 1986'da Zimbabwe'den vereceğim. Komşu ülke Zambiya'daki ekonomik sorunların tartışıldığı bir iktisatçılar toplantısındayım. Dünya Bankası'nın Zambiya'daki temsilciliğini yapmış olan Amerikalı bir iktisaţ̧ı bildirisinde şunları söyledi: "Zambiya'da döviz ihaleleri uygulamasın içeren bir deney yaptık. Başarısız olduk. Şimdi bu konuda bir kitap yazıyorum.”

Dikkat ediniz: Deneyim (“experience") değil, deney ("experiment”) sözcüğünü kullandı. Beklemediği bir tepkiyle karşılaştı. Salonu dolduran Zimbabweli gençler Amerikalı iktisatçıya, (mealen), "bir ülkeyi laboratuvar olarak kullanmaktan ve olumsuz çıkan deney sonuçlarını kitaplaştırtp para kazanmaktan; üstelik bunu marifet gibi bize anlatmaktan utanmiyor musunuz?”

Bu toplantıdan on altı yıl sonra, 2001'de, ünlü iktisatçılardan Stanley Fischer'in Journal of Economic Perspectives dergisinde "Exchange Rate Regimes: Is the Bipolar View Correct" başlıklı yazısını okuyunca, Zimbabwe'deki tartışmayı hatırladım ve Türkiye'nin de Fischer tarafından bir laboratuvar olarak kullanılmış olabileceğinden kuşkulandım.

Hatırlatayım ki, 2000-2001'de Türkiye'de IMF tarafindan döviz kuru hedeflemesine bağlı bir anti-enflasyon programı uygulanmaktaydı. Stanley Fischer bu tarihte IMF'nin baş iktisatçısıdır, Türkiye programını biçimlendirdiği ve çok yakından izlediği de biliniyordu. Türkiye'ye geldiğinde programın başarıyla uygulaması nedeniyle hükümeti överdi.

Ne var ki, programın kendisi krize yatkındı. Bu hususu Yılmaz Akyüz'le birlikte kaleme aldığımız bir makalede ayrıntılarıyla ortaya koyduk. Kaçınılmaz sonucun önbelirtileri Kasım 2000'de ortaya çıktı. Fischer ve IMF heyeti programın aynen 
sürdürülmesinde ısrar etti. 2001 Şubatında finansal kriz tüm ağırlığıyla patlak verdi. Zorunlu olarak kur hedeflemesi çöktü; dalgalı kura geçildi.

Fischer'in sözünü ettiğim makalesi, krizden hemen sonra yayımlandı. Çeşitli ülke örnekleriyle birlikte Türkiye'deki programı da tartışıyor. Programın mimarı ve uygulayıcısı olduğunu açıklamıyor; ancak "Türkiye programı doğruydu; ama Türkler beceremediler" anlamına gelecek bir değerlendirme ile krizin sorumluluğundan sıyrılıyor. Öyle anlaşılıyor ki Fischer için de Türkiye "uygun döviz kuru politikalarını belirlemek için bir deney" olarak kullanılmış; deneyin dayandığı model sağlıklı ve doğru imiş; ancak laboratuvar (Türkiye) arızalı olduğu için sonuç başarısız olmuş. Makalesi (benzerleriyle birlikte) bu deneyi de anlatıyor.

Ortada ağır bir bilimsel etik sorunu vardır. Çift pasaportlu Stanley Fischer daha sonra İsrail Merkez Bankası'na başkanlık yaptı. Birkaç ay önce de, ABD medyasının abartılı övgülerine mazhar olduktan sonra FED'e Başkan Yardımcısı olarak atandı. İleride FED politikalarının ABD ekonomisi üzerindeki etkileri üzerinde bir yazı kaleme alırsa, "deney ve laboratuvar" algılamalarını tetikleyecek üsluptan uzak kalacağına emin olabilirsiniz; zira orası IMF ulemalarından gelen her türlü hikmeti hayranlıkla dinleyenlerin Türkiyesi değildir.

Üçüncü örneği 2008 krizinin çevre ekonomileri üzerindeki yansımalarını dört yıl önce öngören bir iktisatçıdan aktarma yaparak başlayacağım. Şunları yazıyor: "En azından on iki yükselen piyasa ekonomisi, altından kalkamayacaklarl kadar borca batmış durumdadır. Zengin ülkelerdeki çok düşük faiz hadlerinin üzerinde getiri arayan küresel portföyler, yükselen piyasa ekonomilerine kaylyorlar. Bu devam edemez. Yatırımcılar yükselen piyasa borçları üzerinde elde ettikleri yüzde 55'lik ortalama getirinin bir sapkınlı olduğunu algllamalıdır. Gelişmiş ülkelerin liderleri, borçlanmanin bir afyon gibi olduğunu; kısa sürede yüksek başarım sağlayacağınl; uzun-sürede vahim sorunlara yol açacağını fark etmelidirler."

Yerinde, gerçekçi, haklı bir uyarı... Nitekim 2008 krizinden sonra bunalıma giren yükselen ekonomilerin hepsi, bu uyarıda betimlenen dış borçlanma tuzağına sürüklenen, Doğu, Orta Avrupa, Latin Amerika ülkelerinden ve Türkiye'den oluşmaktaydı. Ne var ki, bu uyarıyı yapan kişi, Kenneth Rogoff'tur. Ve bunları yazmadan bir yıl öncesine (2002-3'te) kadar IMF'de baş ekonomisttir. Ve bu görevi sırasında Türkiye gibi ekonomilere IMF'nin stand-by anlaşmalarıyla uygulattırdığı politika, "enflasyon hedeflemesi; yüksek reel faiz; bütçelerde faiz dışl fazla hedeflemesi; esnek kur" öğelerinden oluşuyordu. Bu politika modeli, yapısal-kronik cari açık veren bir çevre ekonomisine uygulanırsa, Rogoff'un öngördüğü, "afyon etkisi yapan sıcak para girişleri altında dış borçların tırmanması" sonucu kaçınılmaz olarak ortaya 
çıkacaktır. Rogoff’un \%55'lik “sapkın getirileri”, Türkiye'de gerçekleşmedi; ama yaklaştı: 2003, 2004 ve 2007'de doların arbitraj getirisi sırasıyla \%52, \%31 ve \%44 idi.

Kenneth Rogoff'un 2004'teki uyarısı, ulusal paralarıyla borçlanamayan gariban çevre ekonomilerinin dış borçları için doğru ve geçerliydi. Ne var ki Rogoff, birkaç yıl sonra bu savını Carmen Reinhart ile birlikte yayımladıkları kitapta metropol ve çevredeki tüm ekonomiler için geçerli ve iç-dış; dolarlı-yerli paralı her türlü borcu kapsayan bir biçimde değiştirdi ve \%90'lık borç/milli gelir oranının bir tehlike eşiği olduğunu iddia etti. Özellikle de Amerika'da ve Avrupa'da kriz ortamında kemer sıkma politikalarını savunan tutucu savlara ampirik destek sağladı.

Ne var ki, sonunda, bir hayli güçlükle kitabın veri tabanına ulaşabilen lisansüstü öğrencileri, Rogoff ve Reinhart'ın hesaplama hatalarını ortaya koydular ve savlarını çökerttiler. Rogoff, hataları gözden kaçırdığını kabul etti; ama ciddiye alınır bir özeleştiri yapmaktan ısrarla kaçındı.

\section{IMF'NIN KRIZZ-ÖNCESI EKONOMIK VE İDEOLOJIK "AT GÖZLÜKLERI””}

Joseph Stiglitz, Dünya Bankası baş iktisatçılığı görevinden ayrıldıktan kısa bir süre sonra, IMF'yi şiddetle eleştirdi. Eleştirilerinden IMF uzmanları da nasiplerini aldı; onları, "ikinci sınıf üniversitelerden mezun üçüncü sınıf iktisatçılar” olarak küçümsedi.

Dünya Bankası'na dönük paralel bir eleştiri (dolayısıyla da özeleştiri) içermeyen bu tavrın samimiyeti elbette sakattır. Ancak, IMF'ye egemen olan iktisat anlayışı, doğrudan doğruya IMF'yi denetlemek için oluşturulan, bağımsız yapıdaki bir teftiş kurulu ("Independent Evaluation Office") tarafından da ağır bir biçimde eleştirilmiştir.

2009'da bu kurula direktör olarak atanan Meksikalı Moises Schwartz'ın yönetiminde "Finansal ve Ekonomik Krize Gidiş içinde IMF'nin Başarım Derecesi: 2004-2007'ye Ilişkin IMF Gözetimi”' başlıklı bir rapor yayımlandı. Burada, uluslararası kriz öncesindeki IMF çalışmalarının yanıltıcı ve zaman zaman yanlış olduğu ileri sürülüyor; kuruma egemen olan iktisat anlayışının ve doğrudan doğruya uzmanların yetersizliği vurgulanıyor. Birkaç aktarma yapıyorum:

"IMF kadrolarının egemen görüşüne göre, piyasaların disiplini, finansal sorunların giderilmesi için yeterlidir. Bu iktisatçılar, gelişkin, incelmiş, çok az denetlenen finansal piyasaların, ileri ekonomilerde krizleri önleyebileceğine inaniyorlardl. Gelişmiş ülke yetkililerinin kendi finansal sistemlerinin sağlam ve esnek olduğuna ilişskin görüşlerini benimsiyorlardı. Bu sistemlerin hem etkin kaynak 
tahsisini sağladı̆̆ına, hem de riskleri daha iyi karşılayabilecek gruplara dă̆ıttığına

inanıyorlardı. Bu yanlış görüşler, risklerin hafife alınması sonucunu verdi."

Rapor, IMF uzmanları saflarında "egemen görüşlere (veya "sürüye") uyum"; "çatlak ses çıkarmama” davranışlarının yaygın olduğunu; mesleki ilerleme için "hakim paradigmayı asla sorgulamayan tavırların yararlı; üsttekilere ters düşen görüşlerin riskli olarak görüldüğ̈̈nü; egemen iktisat doktrinlerine karşı entelektüel bir tutsaklığın, teslimiyetin” ortak tavır olduğunu vurguluyor.

Bu belgenin bulguları, iki yıl sonra (Şubat 2011'de) hazırlanan ikinci bir raporla da teyit edildi.

Balık baştan kokar. Stanley Fischer ve Kenneth Rogoff gibi meslekî etik ilkelerinden yoksun ulema tarafından yönetilen uzman kadrolarda bağımsız, özgün eleştirel bir iktisat geleneğinin yeşermesi, elbette mümkün olamayacakt1.

\section{SONRASI: YERLEŞİK DOKTRINDE REVIZYON ARAYIŞLARI}

2008'e gelindiğinde IMF etkisiz bir uluslararası kurum haline gelmekteydi. Otuz yıldan beri Üçüncü Dünya ülkelerini neo-liberal doğrultuda hizaya getiren bu kuruluşun müşterileri azalmıştı. Doğu Asya krizi sonrasında kredi açtığı ülkelerdeki uyguladığı baskıcı, bunalımı derinleştiren yöntemler, ekonomik çalkantılarla karşılaşan ülkelerde dahi "IMF'den uzak durma" tavrını yaygınlaştırmıştı; kapısı nadiren çalınıyordu. Öyle ki, IMF'nin personel ve diğer cari giderlerini karşılayan ana kaynak faiz gelirleri erimiş; harcamalarda tasarruf gereksinimi gündeme gelmişti.

2007-2008 krizi bu kurumun önemini artırdı. Kriz sonrasındaki ilk (Kasım 2008'deki) G20 toplantısı IMF'nin sorumluluk alanını genişletti; krizin gelişimini izleme, gözetme, politika önlemlerinin koordinasyonu işlevlerinde onu ön plana çıkardı; üyeler 750 milyar dolarlık ek kaynak katkısı üstlendiler. Otuz y1l boyunca çevre ekonomilerinin sağladığı odaklanan deney birikimi, artık metropol ekonomilerine de taşınacaktı.

Bu yeni ortamın IMF üzerindeki etkileri iki doğrultuda izlenebilir.

Bir kere, krizi izleyen iki yıl içinde IMF dünya kamuoyuna alışılmışın dışında farklı bir görüntü ve mesaj vermeyi başardı. Bunda iki Fransızın etkili olduğu söylenebilir. Birincisi, uluslararası krizle eş-zamanlı olarak (Eylül 2007'de) IMF'nin başına getirilen Dominique Strauss-Kahn; ikincisi ise bir y1l sonra Fon'un baş iktisatçılığına atanan Olivier Blanchard. Bu ikili uzunca bir süre, IMF’nin ekonomik söylemlerinin değiştiği algılamasının oluşmasına çaba sarf etti. Aslında geleneksel bir 
makro-iktisatçı olmasına rağmen Blanchard, geçmişe damgasını vuran neo-klasik, parasalcı iktisat anlayışııı eleştiren bir söylem geliştirdi; o doğrultuda yazılar kaleme aldı. IMF'nin araştırma birimlerinde de üst kademedeki değişime ayak uyduran bazı çalışmalar yapıldı; yayımlandı.

İkinci doğrultu ise, doğrudan doğruya uygulamalarla ilgilidir. Mart 2009'da iki yenilik getirildi. IMF kredileri için öngörülen politika koşullarının önceden (ex-ante) belirlenmesine; uygulama başladıktan sonra yeni koşullar ileri sürülememesi kararlaştırıldı. Buna ek olarak, "temel ekonomik göstergeleri çok güçlü olan ekonomilere özgü", esnek kredi hattı adını taşıyan yeni bir kaynak oluşturuldu. Bu kredi, sözü geçen "güçlü” özellikleri taşıyan ülkelere (ihtiyaç doğduğunda kullanılmak üzere) tahsis edilebilecektir. Hatılladığım kadarıyla Polonya ve Meksika esnek kredi hattı uygulamasından yararland. Ne var ki, bu yenilikler, IMF'nin geleneksel stand-by anlaşmalarına yansımadı. Önce kriz ortamına sürüklenen gelişmekte olan ekonomilere; sonra da 2010'da Avro Bölgesi bunalımı sırasında açılan IMF kredileri, hem politika koşulları; hem de uygulamanın izlenmesi açısından geçmiş otuz yılın özelliklerini, tüm ağırlığıyla sürdürdü.

$\mathrm{Bu}$ iki doğrultuyu ayrı ayrı gözden geçirmek istiyorum.

\section{GELENEKSEL DOKTRINDE REVIZYONLAR}

2008-2009'da Olivier Blanchard, kriz öncesine egemen olan iktisat düşüncesini eleştiren birkaç yazı yayımladı. Bu ilk eleştirilerde, Batı ülkelerindeki iktisat yönetimleri hedef alındı.

29 Aralık 2008 tarihli bir yazısında, Blanchard, krize karşı maliye politikalarının önemini vurguluyor. Yazı, kamu harcamalarındaki artı̧ların çoğaltan etkisinin, genel vergi indirimlerinden daha yüksek olduğunu ileri sürmekte; böylece krizin erken aşamasında kemer sıkma söylemlerine karşı çıkmaktadır.

Blanchard 12 Şubat 2010'da, "Ne bildiğimizi sanıyorduk; ne ögrrendik?" başlıklı bir yazı yayımladı. Burada, Batı ekonomilerine egemen iktisat politikası anlayışına dönük bir eleştiri yer alır. Maliye politikasını reddedip, para politikası ile sınırlı tutulan; onu da tek bir hedef (enflasyon) ve tek bir araç (merkez bankalarının politika faizi) ile sınırlı tutan iktisat politikası anlayışının toptan yetersiz, hatta yanlış olduğunu ileri sürdü. Bu çerçevenin egemen olduğu dönemlerin büyük itidal ("the great moderation") söylemi ile yüceltilmesinin de anlamsız olduğunu belirtti.

Geçmişe damgasını vuran bu hataların yerine, Blanchard, ekonomiler küçülürken düşük enflasyon hedeflemesinin yanlış olduğunu; hatta yüksekçe bir enflasyonun deflasyona tercih edilmesini; aktif bir maliye politikasının yeniden gündeme gelmesini 
ve finansal sistemin kuralsızlaştırılması saplantısının terk edilmesini; tam aksine düzenleyici kuralların geliştirilmesini savunuyordu.

Çevre ekonomilerin daha yakından ilgilendiren bir yenilik de, sermaye hareketleri üzerinde kontrollere, kısıtlamalara daima karşı çıkmış olan yerleşik IMF doktrininin revizyonu ile ilgilidir.

Uluslararası kriz, özellikle Doğu Avrupa, bazı Latin Amerika ülkelerinde ve Türkiye'de hızlı yabancı sermaye çıkışlarına yol açtı. Bu etken, 2008-2009'da milli gelirlerin düşmesini tetikledi. Kriz ortamı, "sermaye hareketleri denetlenmeli" önerilerini canlandırdı ve Strauss-Kahn birkaç kere, “öneriler haklıdır” diye görüş belirtti.

19 Şubat 2010'da ve 5 Nisan 2011'de yayımlanan iki IMF çalışması, sermaye hareketlerinde ve dış ticarette serbestliğin ilke olarak yararlı olduğunu; ancak, dış kaynak hareketleri için biraz daha dikkat edilmesini ileri sürüyor. Zira, bunlardaki oynaklığın olumsuz sonuçları kriz içinde açık-seçik ortaya çıkmıştır. 2010'da yeniden canlanan sermaye girişlerinin istikrarsızlıklara yol açmaması için maliye ve para politikası araçları, döviz kuru politikaları, düzenleyici kurallar, döviz piyasalarına müdahaleler ve son çare olarak sermaye hareketlerinin denetlenmesi önerilmektedir.

Sonunda, 14 Aralık 2012 tarihinde IMF bu konudaki (şimdilik) resmi belgesini yayımladı: Sermaye Akımlarının Liberalizasyonu ve Yönetilmesi: Kurumsal Bir Görüş. Biraz önce özetlediğim görüşler, bu belgede de tekrarlanıyor; ancak birkaç yeni öğe de içeriliyor. Başta, sermaye hareketlerinin yararları ile riskleri karşılaştırıldığında yararların ağır bastığı ileri sürülüyor. Ancak, bu yararlar özellikle de finansal ve kurumsal açıdan gelişkin olan ülkelerde öne çıkar. Risklere karşı, önceki belgelerdeki görüşler tekrarlanıyor: Sermaye hareketlerinin denetlenmesi, diğer önlemlerden sonra düşünülmelidir. Ek olarak, yüksek tempoda sermaye ihraç eden ülkelerin de olası olumsuz sonuçları dikkate alması öneriliyor. Ayrıca, ikili ticaret anlaşmalarında yer alan sermaye hareketlerinin serbestleşmesiyle ilgili kuralların, tek yönlü denetimlere tabi olamayacağı ileri sürülüyor.

Böylece, sermaye hareketlerinin serbestleşmesi konusunda geleneksel IMF doktrini, büyük ölçüde korunmuş olmaktadır.

$\mathrm{Bu}$ noktada, genellikle dikkatten kaçan bir başka IMF doktrini üzerinde duracağım. Anne Krueger, IMF Başkan Yardımcısı iken, batık devlet borçlarının, ikinci el piyasalarda "akbaba yatırımcılar" tarafından ucuza satın alınmasından doğan riskleri dikkate alan bir düzenleme yapılmasını önermişti. O zamandan beri, IMF, genellikle, borçlu devletleri, spekülatör ("akbaba") yatırımcılara karşı korumayı savunan bir çizgi 
izledi. Arjantin'in 2002 'de silinen borçlarıla ilgili talepler 2013'de yeniden gündeme gelince IMF Arjantin hükümeti lehine tavır aldı.

Bu tutum, dış borçlarla ilgili (örneğin Avro krizi sonrasında) çeşitli uluslararası anlaşmaları geçersiz kılabilecek olan spekülatif çevrelere karşı çıkılma önceliğini taşımaktadır. Ancak, IMF'nin bu "hayırhah" tavrı, ABD mahkemelerinin Arjantin'e karşı akbaba yatırımcıları gözeten karalarını etkilememiştir.

\section{ÜLKE POLITIKALARI: GELENEKSEL ÇİGGI SÜRDÜRÜLÜYOR}

Doktrindeki revizyon belirtileri, uygulamalara taşınmamıştır. Son uluslararası kriz sonrasında IMF'nin çeşitli ülkelere taşıdığı politika reçeteleri ve koşullar, 1980 sonrasında çevre ekonomilerinde izlenen yaklaşımdan farklı değildir.

Bu konuda ilginç bir araştırmayı, Mark Weisbrot ve arkadaşları yaptı: 20072009'da IMF'nin çevre ekonomileri ile yaptı̆̆ 41 anlaşma mercek altına alındı. Sonuçta, bu anlaşmalardan 31 'inde IMF'nin önerdiği politikalarda, ülkelerdeki kriz ortamını daha da derinleştirici etkenlerin ağır bastığı belirlendi. Buna "çevrimi destekleyen" önlemler deniliyor. Araştırıcılarla IMF arasındaki bir tartışma sonunda da aynı bulgular doğrulandı. Uluslararası krizin ilk aşaması geçildikten sonra, IMF büyük ölçüde Batı ülkelerindeki ekonomik yönetimlere egemen olan kısıtlayıcı bütçe ve genişleyici para politikalarına tam destek verdi. Böylece Britanya, Almanya hükümetlerinin tamamen, ABD'nin ise kısmen finans kapitale teslimiyetini benimseyen odaklardan biri oldu.

Financial Times'ın "sağduyulu sağcı" yazarlarından Martin Wolf, IMF'nin Britanya ekonomisi için yayımladığı rutin raporu, "bu objektif bir değerlendirme değil, Muhafazakâr Parti iktidarına yazılmış bir aşk mektubudur" diye eleştiriyor. 2010'dan itibaren IMF, AB ülkelerine, "harcamaları kısarak bütçe açıklarını daraltın" önerilerinde ısrar etmeye başlamıştı. Bu ısrar bir yandan, olası yeni borç krizlerine karşı bir uyarı gerekçesine dayanıyordu. Ancak aynı zamanda, "genişletici kemer sıkma" savlarını da benimsemiş oluyordu. Yani, kamu maliyesinde kemer sıkma, öylesine olumlu yan etkiler yaratır ki, net sonuç, ekonominin genişlemesi olur.

$\mathrm{Bu}$ sav, kamu harcamalarıyla ilgili çoğaltan etkisinin pozitif olması halinde çökecektir. Bir müddet sonra, Blanchard itiraf etti ve IMF'nin Dünyanın Ekonomik Görünümü raporları teyit etti ki, IMF ampirik çalışmalarında kamu giderlerinin çoğaltan etkisini sıfır civarında kabul etmişti; sonraki hesaplamalarda ise bu değerin 1,5-2 civarında olduğunu belirlemiştir. Böylece kamu harcamalarının 1 dolar aşağı çekilmesi, toplam milli geliri de 1,5-2 dolar düşürecekti. Ne var ki, bu yeni bulgu, ülkelere dönük IMF reçetelerinde revizyona yol açmadı. 
2010 sonrasında IMF kredilerinin yüzde 91'inin Avrupa ülkelerine verildiği belirleniyor. Avro Bölgesi'nin çevresinde patlak veren borç krizinde üstlenilen rol, IMF sicilinde kara bir leke olarak yer alacaktır. Avrupa Birliği, Avrupa Merkez Bankası ve IMF'den oluşan “Troyka"nın, özellikle Yunanistan krizi boyunca bu ülkede uygulattığı insafsız politikaları başka vesilelerle yazarak, konuşarak inceledim, tartışım, eleştirdim. Burada, bu konuya dönmek istemiyorum. Üç saptama ile yetineceğim.

Birinci olarak, siyasete müdahale Troyka, Yunanistan ve İtalya'da seçimlere, güven oylamalarına müdahale etmiş; bir referandumu önlemiş; başbakanları istifaya sürüklemiş; eski bankerlerden teknokrat başbakanlar bulmuş; bunları iktidara getirmiştir. Avro krizine sürüklenen ülkelere bu türden anti-demokratik müdahalelerin bayraktarlığını Almanya sürüklemiştir; ama, IMF de her aşamada bu tutuma tam destek vermiştir.

İkinci olarak, Avro Bölgesi krizlerindeki IMF programları, döviz kuru ayarlaması (devalüasyon) gündem dışı olduğu için, geleneksel istikrar programlarına göre çok daha şiddetli sonuçlar yaratmıştır. Benzer programları uygulayan çevre ekonomilerinde bir veya iki yılla sınırlı olan küçülme, örneğin Yunanistan'da (2007 ile başlatırsak) altı yıl kesintisiz sürmüştür; sürmektedir. IMF programının Yunanistan ekonomisi üzerindeki daraltıcı etkisini yanlış (daha hafif) öngördüklerini Lagarde 7 Mayıs 2013te itiraf etti: "2009-2012 arasinda milli gelirde \%5,5 oraninda daralma öngörmüş̧ük; gerçek daralma \%17 oldu. İşsizliğin \%15'e çıkacağını öngörüyorduk; \%25'e çıtı.” Bu saptamaların sonuçlarını, yarım-ağızlı bir itiraf ile geçiştiriyor: "İnantyoruz ki, kemer sıkma ile büyüme uzlaşabilir; ancak tek başına kemer sıkma büyüme getirmez."

Üçüncü olarak, Syriza ile Troyka arasında Brüksel'de sürdürülen müzakerelerde ağır baskılar sonunda biçimlenen ve Yunan Maliye Bakanı tarafından kaleme alınan nihaî mektup, aslında "kötü polis" rolünü oynayan Almanlar tarafindan dahi kabul edilir. IMF Başkanı ise, "bir karşı oy yazısı" niteliği taşıyan bir mektubu, Troyka grubunun başkanlığını yapan Hollanda Maliye Bakanı'na iletir. Bu mektup, açıkça "Yunanlıların yükümlülüklerini yerine getirebileceği olası görünmüyor; bu hususta hiçbir güvence yoktur" demektedir; yani, örtülü olarak "bunlara güvenilmez" mesajını içermektedir.

Böylece, IMF'nin Yunanistan siyasetine açıkça müdahale etmeyi sürdürmeye kararlı olduğu anlaşllıyor.

Öte yandan, IMF'nin ters yönde, yani “kayırarak” yaptı̆̆ bir başka siyasete müdahale örneğini, Ukrayna'nın iki aylık darbe hükümeti ile yaptığı 17 milyar dolarlık, 
iki yıllık bir kredi anlaşması oluşturuyor. Bu konuyu yakından izleyen bir iktisatçı var, Michael Hudson. Onun yazdıklarını aktarmakla yetineyim:

"Normal IMF uygulamalarında bir yıl içinde verilen kredi, üye ülke kotasının iki mislini aşmaz. Bu kredi ise Ukrayna kotasının sekiz mislidir. IMF ülkedeki çatışmalara rağmen hükümetin ekonomik reformlara bağlllı̆̆ını övmektedir; ama Mayıs başında Ukrayna hazinesine verilen 3,2 milyar doların 3,1 milyarl, A ğustos 'ta offshore hesaplara aktarllarak kaybolmuştur."

Demek oluyor ki, ABD ve AB'nin Ukrayna üzerinden Rusya ile başlattıkları siyasi mücadelede aktif bir taraf olmuştur.

Konuşmamda değindiğim çeşitli olguları, yorumları bir genelleme ile toparlayabileceğimi düşünüyorum: IMF emperyalizmin bir üst-organıdır. Kırk yıl önce yeni işlevlerle zenginleşen bu özellik, 2007-2008 krizinden sonra da pekişmiştir; genişlemiştir: süregelmektedir.

Sabrınız için hepinize teşekkürler; saygılar; sevgiler... 